\title{
Optimum Conditions for Bioethanol Production from Potato of Bangladesh
}

\author{
Abul Kalam Azad1, Nilufa Yesmin1, Shanjit Kumar Sarker1, Abdus Sattar², Rezaul Karim³ \\ ${ }^{1}$ Institute of Environmental Science, Rajshahi University, Rajshahi, Bangladesh \\ ${ }^{2}$ Institute of Food Science \& Technology, Bangladesh Council of Scientific and Industrial Research (BCSIR), \\ Dhaka, Bangladesh \\ ${ }^{3}$ Department of Biochemistry and Molecular Biology, Rajshahi University, Rajshahi, Bangladesh \\ Email: ${ }^{*}$ akazad ies@yahoo.com
}

Received 4 February 2014; revised 8 April 2014; accepted 30 April 2014

Copyright (C 2014 by authors and Scientific Research Publishing Inc.

This work is licensed under the Creative Commons Attribution International License (CC BY).

http://creativecommons.org/licenses/by/4.0/

c) (i) Open Access

\begin{abstract}
Bangladesh produces a huge amount of potatoes every year. This research was carried out to find the optimum conditions for bioethanol production from potato of Bangladesh. From this study, optimum growth of yeast (Saccharomyces cerevisiae $\mathrm{CCD}$ ) was observed at $\mathrm{pH} 6.0$ and temperature $31^{\circ} \mathrm{C}$. Addition of a small amount of alpha-amylase enzyme to potato solution was found to enhance the potato starch degradation and made the fermentation process quicker. This study observed that 1750 unit alpha-amylase is enough to degrade the starch in $15 \%$ of $500 \mathrm{ml}$ potato starch solution. From fermentation time study, 6-day incubation time was found to be enough to complete the fermentation process and optimum production of bioethanol form potato starch. Suitable concentration of potato in fermentation process was determined using five different potato solutions $(5 \%, 10 \%, 15 \%, 20 \%$ and $30 \%)$. A highest production of bioethanol was found in $20 \%$ potato treatment. Therefore, $20 \%$ potato solution is recommended for high-scale production of bioethanol from potato starch.
\end{abstract}

\section{Keywords}

Potato, Bio-Ethanol, Fermentation, Alpha-Amylase

\section{Introduction}

Energy in all its forms is essential to humanity and is central to the improvement in people's quality of life. The continuous increase in energy demand, the inevitable decline in the availability of fossil fuels, and the growing concerns about climate change have sparked a number of initiatives from governments around the world to in-

\footnotetext{
"Corresponding author.
}

How to cite this paper: Azad, A.K., Yesmin, N., Sarker, S.K., Sattar, A. and Karim, R. (2014) Optimum Conditions for Bioethanol Production from Potato of Bangladesh. Advances in Bioscience and Biotechnology, 5, 501-507. 
crease production of energy from renewable sources [1]. Ethanol fermented from renewable resources or biomass-based materials for fuel is considered as bio-ethanol [2]. Biofuels, and in particular bioethanol, i.e. ethanol obtained from crops or lignocellulosic biomass, are getting a lot of attention as a possible option for renewable transportation fuel. Countries with tropical weather condition, such as Brazil, have successfully utilized sugarcane (Saccharum officinarum) for decades as the main feedstock to produce ethanol [3]. However, some studies showed a low power density value [4]. Due to the low cost of sugarcane, other countries in Africa, Latin America, and Asia have plans to increase their production of ethanol from sugarcane [5]. In the United States and Europe, ethanol is produced mainly from corn and grain [6]. Other starchy crops being utilized are sorghum (Sorghum sp.) grains, cassava (Manihot esculenta), and potatoes (Solanum tuberosum ssp tuberosum) [7]. However, there is currently a substantial amount of research being done concerning the development of cellulosic bioethanol [8], but the process for producing it is not yet at a commercial level. Rapeseed (Brassica sp.), sunflower (Helianthus annus), sugar beet (Beta vulgaris var saccarifera), wheat (Triticum vulgaris), and potatoes have been considered as potential feedstock for the production of biofuels. In addition, several studies have focused in the production of ethanol from sugar cane in Brazil and other countries.

Bangladesh imports most of the oil from Middle East by spending valuable foreign currencies. In 2011 fiscal year, Bangladesh spent 5.0 billion US dollars for oil import and in 2012 this cost is around 6.17 billion dollars. This huge spend on oil import has created tremendous pressure on Bangladesh's annual budget. However, Bangladesh can easily reduce its oil import with the production of renewable fuel like bioethanol from sugarcane, corn, potato and sweet potato. Bangladesh produces a huge amount of potatoes and sweet potatoes, which are expected to be used as the promising source of bioethanol. For huge production of potato, Bangladesh's farmers deprived of retail price every year. Alternate use of potato like bio-ethanol production would ensure potato price at farmer's level. Therefore, this project was done considering the following objectives:

1) To evaluate the Bangladeshi potato as raw materials for bioethanol production; and

2) To find out the optimum conditions for bioethanol production from potato.

\section{Methodology}

\subsection{Potato Sample Collection}

Potato (cardinal variety) was collected from the vegetable market of Rajshahi, Bangladesh. Potato was washed and cut into several pieces and boiled in water for 25 - 30 minutes. A suitable amount of boiled potato was taken for experiment purpose.

\subsection{Yeast Strain and Culture Media}

Yeast strain (Saccharomyces cerevisiae CCD) was collected from the Spirit Section of Carew and Co., Darsana, Bangladesh.

For yeast culture, modified YMPD (Yeast-Malt-Peptone-Dextrose) broth culture was used. Composition of this culture media is given in Table 1. Generally, dextrose is used in yeast media as carbon source. But, we used boiled potato mash instead of dextrose in modified YMPD broth culture media for propagation of yeast cell during bioethanol production.

\subsection{Determination of Optimum pH and Temperature for Yeast Growth}

To determine the optimum $\mathrm{pH}$, yeast strain was cultured in modified YMPD broth culture media (300 ml) with different $\mathrm{pH}$ 3.0, 4.0, 5.0, 6.0, 7.0 and 8.0 at $32^{\circ} \mathrm{C}$. The optimum temperature was measured by using the same YMPD media at fixed $\mathrm{pH} 6.0$ with incubating at different temperatures, $25^{\circ} \mathrm{C}, 28^{\circ} \mathrm{C}, 31^{\circ} \mathrm{C}, 34^{\circ} \mathrm{C}, 37^{\circ} \mathrm{C}$ and $40^{\circ} \mathrm{C}$.

Yeast cell growth was monitored every 12 hours for $\mathrm{pH}$ experiment and every 24 hours for temperature experiment. For determination of growth, turbidity of YMPD broth culture media was measured at $610 \mathrm{~nm}$.

\subsection{Determination of Fermentation Time}

For fermentation time study, $100 \mathrm{ml}$ of one-day old yeast was added in $400 \mathrm{ml}$ potato solution (15\%) and incubated at $31^{\circ} \mathrm{C}$ for 5-different incubation periods (4, 5, 6, 7 and 8-days). Bio-ethanol production was measured after each interval. Crude fermented potato solution was first centrifuged at 12,000 rpm to remove the unused starch and yeast cell. Then, the clear solution was taken into rotary evaporator for separation of ethanol at 
$78.5^{\circ} \mathrm{C}$ for five minutes.

\subsection{Alpha-Amylase Enzyme for Optimum Degradation of Potato Starch}

To find out the suitable enzyme activity for optimum degradation of potato starch, different enzyme activities (350, 700, 1050, 1400, 1750 and 3500 unit) of alpha-amylase enzyme was added into $300 \mathrm{ml}$ potato solution (15\%). Then, $100 \mathrm{ml}$ of one-day yeast culture was added and incubated at $31^{\circ} \mathrm{C}$. Ethanol production was measured after 6-days incubation period.

\subsection{Determination of Potato Concentration for Optimum Production of Bioethanol}

Suitable potato concentration is important for getting the highest production of ethanol. Therefore, different concentration potato starch (5\%,10\%, 15\%, 20\% and 30\%) was prepared in $400 \mathrm{ml}$ distilled water. About 1750 unit of alpha-amylase enzyme and $100 \mathrm{ml}$ of yeast was added to each treatment and incubated at $31^{\circ} \mathrm{C}$ for 6 -days. Fermentation $\mathrm{pH}$ and temperature was adjusted to the optimum condition during this experiment. After incubation period, turbidity of solution and produced ethanol were measured.

\subsection{Measurement of Purity of Produced Alcohol}

The percent of purity of produced bioethanol from potato was measured by using an alcohol meter (Jiujingnongduji, China). This meter can measure the alcohol purity from 0 to 100 percent.

\subsection{Flow Chart of Bioethanol Production from Potato}

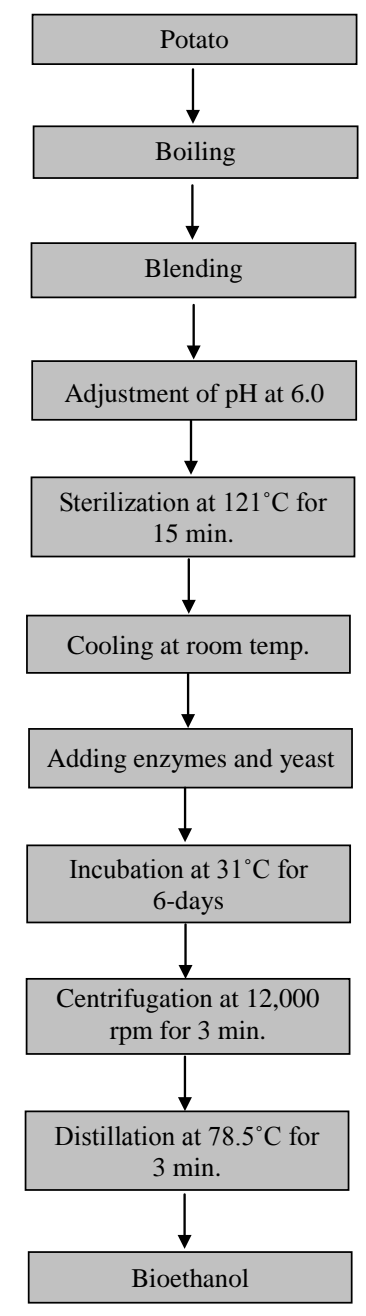


Table 1. Composition of modified YMPD broth culture media.

\begin{tabular}{ccc}
\hline Ingredients & Amount (g) \\
\hline Yeast extract & 3.0 \\
Malt extract & 3.0 \\
Peptone & 5.0 \\
Potato mash & 10.0 \\
Distilled water & $1000 \mathrm{ml}$ \\
$\mathrm{pH}$ & 6.0 \\
\hline
\end{tabular}

\section{Results and Discussion}

\subsection{Optimum pH and Temperature for Yeast Growth}

From experimental six $\mathrm{pH}$ (3.0, 4.0, 5.0, 6.0, 7.0 and 8.0), the highest yeast growth was found at $\mathrm{pH} 6.0$ (Figure 1). Therefore, $\mathrm{pH} 6.0$ is considered as the suitable $\mathrm{pH}$ for yeast growth and fermentation of potato.

Khan et al. (2012) mentioned optimum pH 5.5 for the production of bioethanol from potato [9]. This $\mathrm{pH}$ is very close to present optimum $\mathrm{pH} 6.0$ (Figure 1 ).

Out of six tested temperature $\left(25^{\circ} \mathrm{C}, 28^{\circ} \mathrm{C}, 31^{\circ} \mathrm{C}, 34^{\circ} \mathrm{C}, 37^{\circ} \mathrm{C}\right.$ and $\left.40^{\circ} \mathrm{C}\right)$, optimum yeast cell growth was found at $31^{\circ} \mathrm{C}$ (Figure 2).

\subsection{Fermentation Time for Bioethanol Production}

For optimum conversion of potato starch by yeast, sufficient incubation time or fermentation time is required. From this experiment, it is found that 6-days incubation period is good for optimum bioethanol production (Figure 3). Long-time incubation reduced the bioethanol production because potato contains not only starch but also protein and fat. Energy from protein and fat help yeast to convert ethanol into other products and resulting a low ethanol formation was observed after 6-days during this study.

\subsection{Alpha-Amylase Enzyme for Degradation of Potato Starch}

Yeast is necessary for fermentation but addition of enzyme enhances the conversion of starch into sugar as well as increases the fermentation process and bioethanol production [9]. The starchy polymers of biomass need to be converted to simple sugars before fermentation through a process called hydrolysis [10]. The most commonly methods are chemical hydrolysis and enzymatic hydrolysis [11]. In absence of alpha-amylase enzyme, yeast (Saccharomyces cerevisiae CCD) was found to ferment potato starch very slowly and also made unwanted red or purple color. However, addition of small amount of alpha-amylase enzyme caused rapid fermentation with characteristic smell of alcohol. From this study, we found optimum bioethanol production in 1750 unit alpha-amylase treatment (Figure 4). Therefore, it is concluded that 1750 unit alpha-amylase enzyme is enough to degrade the starch into simpler disaccharide or monosaccharide of $500 \mathrm{ml}$ potato solution (15\%) and optimum production of bioethanol. A high concentration of enzyme causes feed-back inhibition to reaction process [12] and resulting a less amount of substrate (potato) converted into ethanol during application of 3500 unit of alpha-amylase enzyme in fermentation process (Figure 4).

\subsection{Concentration of Potato for Optimum Bioethanol Production}

Suitable potato concentration is important for highest production of ethanol. Out of five tested potato concentration (5\%, 10\%, 15\%, 20\% and 30\%), all of the treatments except 30\% produced clear white color layer in upper part of fermented potato solution. That means all potato starches in 5\%, 10\%, 15\% and $20 \%$ are converted into ethanol during this incubation period. On the other hand, opalescent and turbid color (OD 0.246) was found in $30 \%$ potato starch treatment (Table 2 ).

Low concentration of potato provided a low yield of bioethanol, however, bioethanol production was found to increase with increase of potato up to $20 \%$ in solution. In $30 \%$ potato, bioethanol production was found to decrease because of less production of free glucose for incomplete saccharification of starch. Addition of 1750 unit 


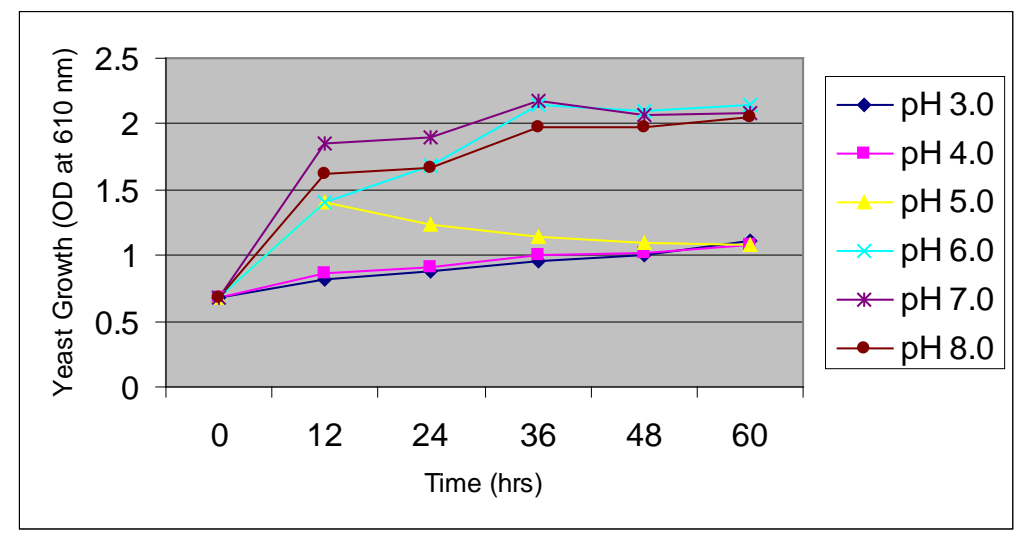

Figure 1. Optimum $\mathrm{pH}$ for yeast growth in modified YMPD broth media.

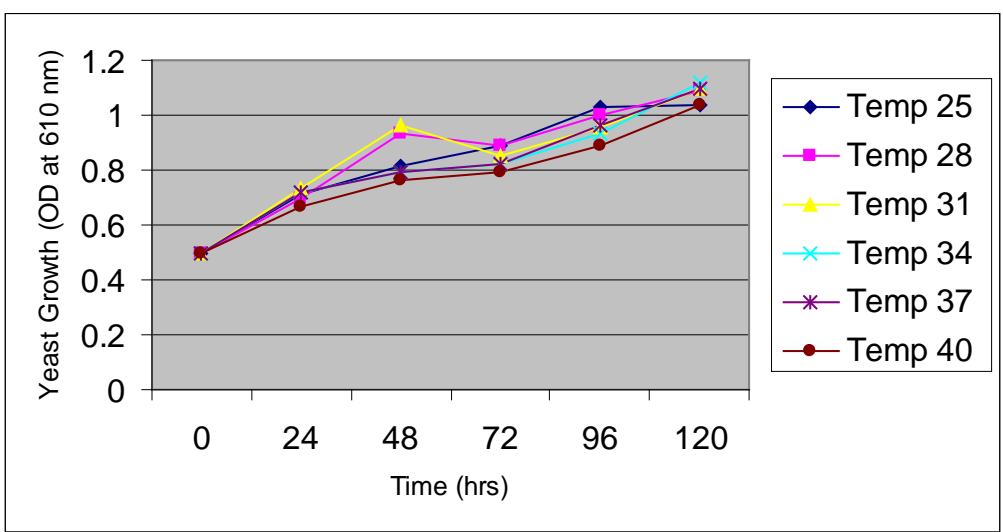

Figure 2. Optimum temperature for yeast growth in modified YMPD broth media.

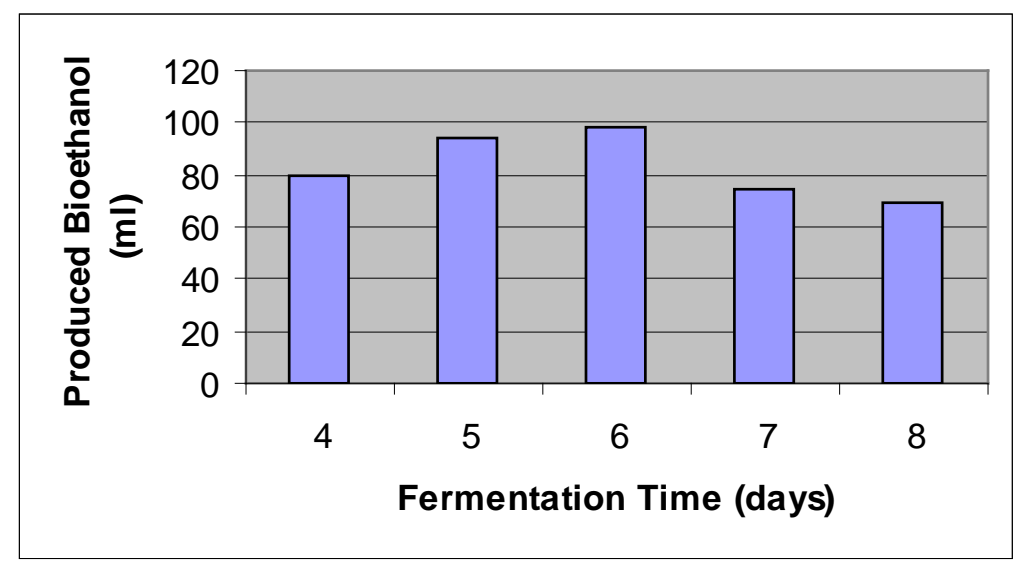

Figure 3. Fermentation time for optimum bioethanol production.

alpha-amylase enzyme to $30 \%$ potato solution is not enough to saccharify a high amount of starch present in this solution (Table 2). As a result, a high turbidity of potato solution as well as less bioethanol production was observed. From this study, 20\% potato solution was found optimum for bioethanol production.

\subsection{Purity of Bio-Ethanol}

The purity of ethanol was found low, $10 \%$ to $12 \%(\mathrm{v} / \mathrm{v})$. 


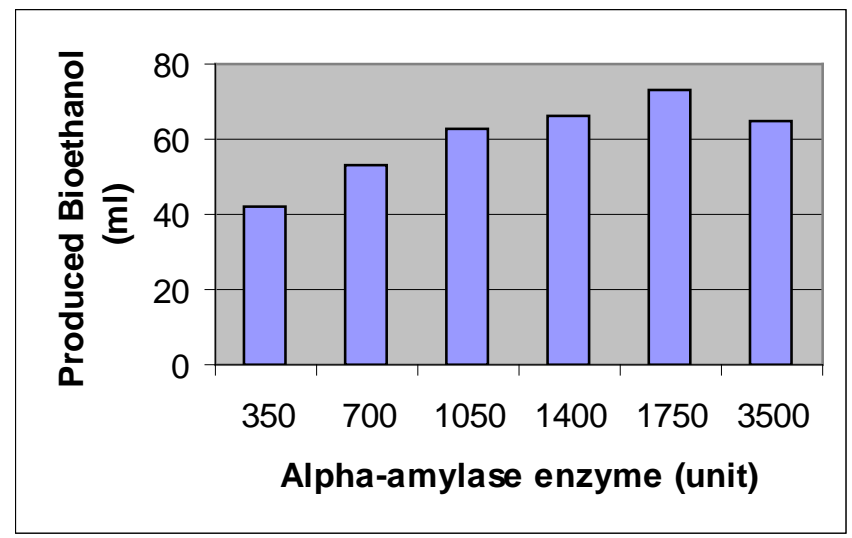

Figure 4. Alpha-amylase enzyme effect on bioethanol production.

Table 2. Bioethanol production from different concentration of potato.

\begin{tabular}{|c|c|c|c|c|c|}
\hline $\begin{array}{c}\text { Potato } \\
\text { Concentration }\end{array}$ & $\begin{array}{l}\text { Potato Sample } \\
\text { Volume (ml) }\end{array}$ & $\begin{array}{c}\text { Alpha-Amylase } \\
\text { (unit) }\end{array}$ & $\begin{array}{c}\text { Fermentation Time } \\
\text { (days) }\end{array}$ & $\begin{array}{c}\text { Turbidity } \\
\text { (OD at } 610 \mathrm{~nm} \text { ) }\end{array}$ & $\begin{array}{c}\text { Produced } \\
\text { Ethanol (ml) }\end{array}$ \\
\hline $5 \%$ & $500 \mathrm{ml}$ & 1750 unit & 6 days & 0.002 & $8.0 \mathrm{ml}$ \\
\hline $10 \%$ & $500 \mathrm{ml}$ & 1750 unit & 6 days & 0.002 & $15.0 \mathrm{ml}$ \\
\hline $15 \%$ & $500 \mathrm{ml}$ & 1750 unit & 6 days & 0.039 & $45.0 \mathrm{ml}$ \\
\hline $20 \%$ & $500 \mathrm{ml}$ & 1750 unit & 6 days & 0.001 & $65.0 \mathrm{ml}$ \\
\hline $30 \%$ & $500 \mathrm{ml}$ & 1750 unit & 6 days & 0.246 & $9.4 \mathrm{ml}$ \\
\hline
\end{tabular}

\section{Conclusions}

From this study, optimum conditions for bioethanol production from potato were established. These conditions are summarized below:

- Optimum $\mathrm{pH}$ and temperature for yeast cell growth were 6.0 and $31^{\circ} \mathrm{C}$, respectively.

- A small amount of alpha-amylase enzyme, about 1750 unit was found to be suitable for enzymatic degradation of starch in $500 \mathrm{ml}$ potato solution (20\%).

- 6-day incubation time was found optimum for bioethanol production.

- $20 \%$ potato solution exhibited highest production of bioethanol from potato starch.

\section{Acknowledgements}

This study was conducted under the financial assistance of Ministry of Science and Technology of Government of the Peoples Republic of Bangladesh (grant number-006.01.00.042.2012-2013/BS-66).

\section{References}

[1] Quintero, J.A., Montoya, M.I., Sanchez, O.J., Giraldo, O.H. and Cardona C.A. (2008) Fuel Ethanol Production from Sugarcane and Corn: Comparative Analysis for a Colombian Case. Energy, 33, 385-399. http://dx.doi.org/10.1016/j.energy.2007.10.001

[2] Grassi, G. (1999) Modern Bioenergy in the European Union. Renewable Energy, 16, 985- 990. http://dx.doi.org/10.1016/S0960-1481(98)00347-4

[3] Wheals, A.E., Basso, L.C., Alves, D.M.G. and Amorim, H.V. (1999) Fuel Ethanol after 25 Years. Trends in Biotechnology, 17, 482-487. http://dx.doi.org/10.1016/S0167-7799(99)01384-0

[4] Ferguson, A.R.B. (2008) The Power Density of Ethanol from Brazilian Sugarcane. In: Biofuels, Solar and Wind as Renewable Energy Systems: Benefits and Risks, Springer, Dordrecht, 493-498. http://dx.doi.org/10.1007/978-1-4020-8654-0_19

[5] Worldwatch Institute (2007) Biofuels for Transportation: Global Potential and Implications for Sustainable Agriculture and Energy in the 21st Century. Worldwatch Institute, Washington DC.

[6] Rutz, D. and Janssen, R. (2007) Biofuel Technology Handbook. WIP Renewable Energies, Munich. 
[7] Liimatainen, H., Kuokhanen, T. and Kaariainen, J. (2004) Development of Bio-Ethanol Production from Waste Potatoes. Proceedings of the Conference of Waste Minimization and Resources Use Optimization, Oulu, 10 June 2004, 123-129.

[8] Milken, J., Josec, F., Wang, M. and Yuzugullu, E. (2007) The Advanced Energy Initiative. Journal of Power Sources, 172, 121-131. http://dx.doi.org/10.1016/j.jpowsour.2007.05.030

[9] Khan, R.A., Nawaz, A., Ahmed, M., Khan, M.R., Dian, F., Azam, N., Ullah, S., Sadullah, F., Ahmad, A., Shah, M.S. and Khan, N. (2012) Production of Bioethanol through Enzymatic Hydrolysis of Potato. African Journal of Biotechnology, 11, 6739-6743.

[10] Taherzadeh, M.J. and Karimi, K. (2007) Acid-Based Hydrolysis Processes for Ethanol from Lignocellulosic Materials: A Review. BioResources, 2, 472-499.

[11] Balat, M. (2011) Production of Bioethanol from Lignocellulosic Materials via the Biochemical Pathway: A Review. Energy Conversion and Management, 52, 858-875. http://dx.doi.org/10.1016/j.enconman.2010.08.013

[12] Lehninger, A.L. (1978) Biochemistry. 2nd Edition, Worth Publishers, Inc., New York, 234-245. 